\title{
UJI EFEK ANTIDIARE EKSTRAK ETANOL DAUN SAWO (MANILKARA ZAPOTA L.) TERHADAP MENCIT JANTAN DENGAN METODE TRANSIT INTESTINAL
}

\author{
Abdul Rahman Wahid, Alvi Kusuma Wardani, Rindi Astuti \\ Program Studi Farmasi, Universitas Muhammadiyah Mataram, \\ rahmanapt@yahoo.co.id
}

\section{INFO ARTIKEL}

\section{Riwayat Artikel:}

Diterima: 18 -05-2018

Disetujui: 28 -07 -2018

\section{Kata Kunci:}

\section{Antidirae}

Manicara Zapota L.

Rat

\section{A. LATAR BELAKANG}

Diare adalah suatu keadaan dimana frekuensi defekasi melebihi frekuensi normal dengan konsistensi feases yang encer [1]. Dehidrasi akibat diare merupakan merupakan salah satu penyebab kematian penting pada anak-anak [2]. Penyakit diare masih menjadi masalah kesehatan terutama di negara-negara berkembang salah satunya indonesia. Dasar pengobatan diare adalah pemberian cairan, dietetik, dan obat-obatan termasuk obat tradisional [3]. salah satu tanaman yang berkhasiat sebagai obata dalah sawo manila (Manilkara zapota L.). Tanaman sawo banyak ditemui di pulau Lombok, salah satunya di kabupaten Lombok Utara. Tanaman sawo mengandung senyawa-senyawa kimia meliputi flavonoid, saponin dan tanin [4]. Tannin merupakan salah satu zat yang berkhasiat sebagai adstringensia sehingga diduga mampu memberikan efek antidiare. Dari latar belakang tersebut maka peneliti ingin menunjukkan efek antidiare ekstrak etanol daun sawo terhadap mencit jantan dengan metode transit intestinal.

\section{B. METODE PENELITIAN}

\section{Pembuatan simplisia}

Sebanyak $3 \mathrm{~kg}$ daun sawo (Manilkara Zapota L.) dipisahkan dari kotoran-kotoran yang menempel kemudian dicuci hingga bersih dan ditiriskan, daun sawo yang sudah bersih tersebut diletakan diatas nampan kemudian dikeringkan dengan sinar matahari atau dimasukan kedalam oven yang bersuhu $50^{\circ} \mathrm{C}$, daun sawo yang sudah kering kemudian dihaluskan menggunakan blender sampai menjadi serbuk yang halus.

\section{Proses pembuatan ekstrak}

Sebanyak 300 gram daun sawo kering ditambahkan etanol sampai simplisia daun sawo terendam sempurna. Maserasi dilakukan sebanyak 3 kali Hasil penyarian dipekatkan dengan waterbath sederhana. 


\section{Pengelompokan dan perlakukan hewan uji}

Hewan uji dibagi secara acak menjadi enam kelompok yakni kelompok normal, kelompok kontrol negative, kelompok kontrol positif dan kelompok uji dengan dosis uji $50 \mathrm{mg} / \mathrm{KgBB}, 100 \mathrm{mg} / \mathrm{KgBB}$, dan 150 $\mathrm{mg} / \mathrm{KgBB}$. Tiap kelompok terdiri dari lima ekor mencit jantan. Mencit dipuasakan terlebih dahulu \pm 12 jam dengan tetap diberi minum ad libitum sebelum perlakukan.

\section{Pengujian Sampel terhadap Hewan Uji Mencit}

Padawaktu $t=0$, semua kelompok diberi perlakuan secara oral dan di beri larutan oleum ricini untuk member efek diare pada mencit dan setelah 1 jam pemberian lalu dilakukan perlakuan. Kelompok normal (I) diberi larutan CMC-Na. Kelompok positif (II) diberi obat suspensi Loperamid-HCl dengan volume pemberian $1 \mathrm{ml} / \operatorname{1oogBB}$,dan kelompok III diberi larutan oleum ricini sebagai pembanding untuk diare dan tidak diberikan obat maupun ekstrak dan kelompok IV, V, dan VI masing-masing diberi ekstrak etanol daun sawo dengan dosis 50, 100, dan $150 \mathrm{mg} / \mathrm{Kg} \mathrm{BB}$ dengan volume masing-masing sebanyak $1 \mathrm{ml} / 100 \mathrm{~g} \mathrm{BB}$. Setelah $\mathrm{t}=45$ menit semua hewandiberi suspensi norit secara oral $0,1 \mathrm{ml} / 10 \mathrm{~g}$ BB. Pada $\mathrm{t}=65$ menit semua hewan dikorbankan secara dislokasi tulang leher. Usus dikeluarkan secarahati-hati, sampai teregang.Panjang usus yang dilalui marker norit mulai dari pylorus sampai ujung akhir (berwarna hitam) diukur. Demikian pula panjang seluruh usus dari pylorus sampai rectum dari masing-masing hewan. Kemudian dari masingmasing hewandihitung rasio normal jarak yang ditempuh marker terhadap panjang usus seluruhnya.

\section{HASIL DAN PEMBAHASAN}

Pengujian efek antidiare ini menggunakan metode transit itestinal yang diinduksi oleh Oleum ricini. Pada tansit intestinal digunakan Oleum ricini sebagai kontrol negatif yang berfungsi sebagai penginduksinya. Oleum ricini merupakan trigliserida dari asam risinoleat yang dapat terhidrolisis dalam usus oleh lipase menjadi gliserin dan asam risinoleat. Sebagai surfaktan anionik zat ini bekerja mengurangi absorpsi neto cairan dan elektrolit serta menstimulasi peristaltik usus, sehingga Oleum ricini dapat menyebabkan diare. Prinsip metode transit intestinal ini adalah membandingkan panjang usus yang dilalui marker terhadap panjang usus keseluruhan. Marker yang digunakan adalah suspensi norit $5 \%$ dalam $\mathrm{Na}$ CMC $0,5 \%$. Norit merupakan senyawa yang bersifat adsorbensia dan tidak dapat dicerna. semakin kecil rasio usus maka dinyatakan memberikan efek antidiare lebih baik. Rerata aktivitas antidiare dapat dilihat pada tabel 1.

TABEL 1.

RERATA AKTIVITAS ANTIDIARE EKSTRAK DAUN SAWO (MANILKARA ZAPOTA L.) SELAMA 1 HARI

\begin{tabular}{lcc}
\hline Kelompok & $\begin{array}{l}\text { Dosis } \\
\text { (mg/kgBB }\end{array}$ & Mean \pm SD \\
\hline Normal & - & $0.6820 \pm 0.12598^{\mathrm{a}}$ \\
\hline $\begin{array}{l}\text { Kontrol } \\
\text { loperamid (+) } \\
\text { Kontrol Olium } \\
\text { ricini (-) }\end{array}$ & $1 \mathrm{ml} / 100 \mathrm{BB}$ & $0.6560 \pm 0.19178^{\mathrm{b}}$ \\
& 150 & $0.1740 \pm 0.4037^{\mathrm{a}}$
\end{tabular}

\begin{tabular}{lcc} 
Dosis I & 50 & $0.8460 \pm 0.5273^{\text {ac }}$ \\
Dosis II & 100 & $0.7620 \pm 0.5293^{\text {ad }}$ \\
Dosis III & 150 & $0.5280 \pm 0.27197^{\text {ae }}$ \\
\hline
\end{tabular}

Keterangan : (1) $\mathrm{P}<0,05$ huruf yang sama menunjukkan berbeda bermakna; (2) P>0,05 huruf yang berbeda menunjukkan tidak berbeda bermakna.

Hasil analisis statistik OneWay Anova menunjukkan bahwa kelompok negatif yang diberikan Olium ricini $(0.1740 \pm 0.4037)$ menunjukkan berbeda signifikansi $(\mathrm{P}<0,05)$ dengan kelompok perlakuan normal $(0.6820 \pm 0.12598)$, dosisi I $(0.8460 \pm 0.5273)$, dosis II $(0.7620 \pm 0.5293)$ dan dosis III $(0.5280 \pm 0.27197)$. hal ini menunjukkan bahwa kelompok Olium ricini mampu membuat kondisi diare pada setiap perlakuan tersebut. Pemberian dosis $(50 \mathrm{mg} / \mathrm{kgBB})$ menunjukkan perbedaan yang nyata, artinya sudah menunjukkan efek antidiare, meskipun masih berbeda nyata dengan pemberian suspensi loperamid (1ml/1oogBB). Pemberian dosis $100 \mathrm{mg} / \mathrm{kgBB}$ dapat bersifat sebagai antidiare (0.7620 \pm 0.5293$)$ yang sama dengan dosis loperamid $(0.6560 \pm 0.19178)$, arti nya taraf signifikansi $(\mathrm{P}>0,005)$. Sedangkan dosis $150 \mathrm{mg} / \mathrm{kgBB}$ menunjukkan berbeda tidak signifikansi $(\mathrm{P}>0,05)$ terhadap dosis normal dan dosis suspensi loperamid, artinya dosis $150 \mathrm{mg} / \mathrm{kgBB}$ mempunyai khasiat sebagai antidiare tetapi tidak bermakna dan tidak menunjukan perbedaan yang signifikansi. Grafik rasio transit intestinal tiap kelompok selama 1 hari dapat dilihat dibawah ini.

\section{Transit Intestinal}

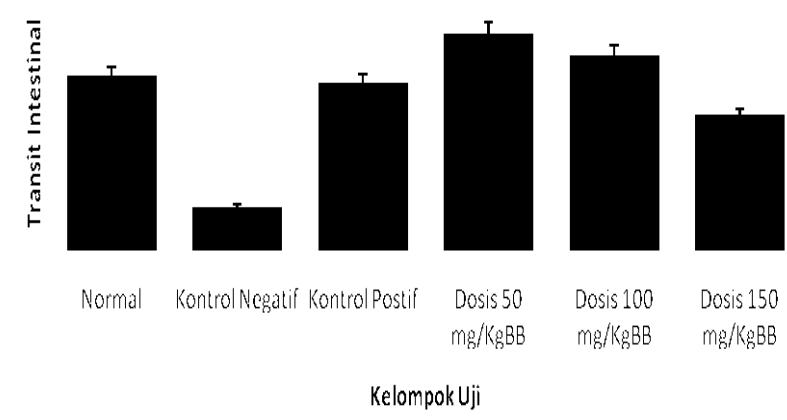

Gambar 1. Hasil rasio transit intestinal usus mencit pada tiap kelompok uji selama 1 hari. Ket : Tiap kelompok terdiri 5 ekor tikus. (1) $\mathrm{P}<0,05$ huruf yang sama menunjukkan berbeda bermakna; (2) $\mathrm{P}>0,05$ huruf yang berbeda menunjukkan tidak berbeda bermakna.

Dari gambar 1 dapat dilihat nilai transit intestinal pada masing-masing kelompok. Kelompok normal merupakan kelompok mencit yang tidak diberikan paparan maupun perlakuan. Kelompok normal bias disebut dengan kelompok sehat. Keadaan usus yang baik adalah ketika nilai rasio transit intestinal mendekati rasio kelompok normal. Data rata-rata hasil pengukuran nilai rasio perambatan marker pada usus mencit terlihat bahwa kelompok normal mempunyai nilai rasio transit intestinal sebesar 0,682. Kelompok kontrol negatif mempunyai nilai rasio terkecil yaknio,1740. Kelompok kontrol negative adalah kelompok yang diberi paparan Oleum ricini sebagai perang sangat timbulnya diare 
tanpa diberikan perlakuan sehingga dapat disebut sebagai kelompok sakit. Kelompok kontrol positif mempunyai rasio mendekati kelompok normal. Kelompok kontrol positif merupakan kelompok yang diberikan paparan sekaligus diberikan perlakuan dengan obat antidiare kimiawi loperamide- $\mathrm{HCl}$ dengan dosis 1 $\mathrm{ml} / 100 g B B$.

Pada kelompok uji, kelompok yang memiliki nilai rasio transit intestinal mendekati kelompok normal adalah kelompok uji yang diberi perlakuan dosis $100 \mathrm{mg} / \mathrm{KgBB}$ dengan nilai rasi o0,07620 dan kelompok uji dengan dosis $150 \mathrm{mg} / \mathrm{KgBB}$ dengan rasio transit intestinal 0,05280 , hal ini dikarenakan besarnya kadar senyawa tanin pada ekstrak daun sawo (Manilkara zapota L.). Hasil skrining fitokimia ekstrak etanol daun sawo manila (Manilkara zapota L) menunjukkan bahawa daun sawo manila mengandung senyawa fitokimia seperti alkaloid, flavonoid, tannin, dan saponin manila (Manilkara zapota L) [7] ditunjukkan pada Tabel 2.

TABEL 2.

HASIL SKRINING FITOKIMIA DAUN SAWO MANILA (MANILKARA ZAPOTA L)

\begin{tabular}{lc}
\hline \multicolumn{1}{c}{ Tes } & Hasil \\
\hline Alkaloid & + \\
Flavonoid & + \\
Tanin & + \\
Saponin & + \\
\hline
\end{tabular}

Penelitian ini sejalan dengan hasil penelitian Winda (2010) pada aktivitas antidiare dengan dosis perlakuan $20 \mathrm{mg} / \mathrm{kgBB}, 40 \mathrm{mg} / \mathrm{kgBB}$ dan $80 \mathrm{mg} / \mathrm{kgBB}$ yang menyatakan bahwa dosis $80 \mathrm{mg} / \mathrm{kgBB}$ mempunyai efek yang lebih kuat dibandingkan dengan Loperamid $\mathrm{HCl}$ [8].

Berdasarkan hasil yang didapatkan pada uji aktivitas antidiare ekstrak etanol daun sawo manila dapat diketahui bahwa ekstrak daun sawo manila memiliki efek sebagai antidiare yang ditunjukkan dengan nilai rasio transit intestinal mendekati nilai rasio kelompok normal pada dosis $100 \mathrm{mg} / \mathrm{KgBB}$ dan 150 $\mathrm{mg} / \mathrm{KgBB}$. Hal ini kemungkinan disebabkan oleh adanya kandungan senyawa tanin yang tinggi pada daun sawo manila. Tanin merupakan zat adstringensia yang mampu berikatan dengan membran mukosa sehingga mampu membentuk pembatas yang resisten sehingga mampu mengurangi cairan yang masuk kedalam saluran cerna [5].

\section{KESIMPULAN DAN SARAN}

Hasil penelitian ini menunjukkan bahwa pemberian dosis ekstrak daun sawo (Manilkara Zapota L.) $100 \mathrm{mg} / \mathrm{kgBB}$ dan $150 \mathrm{mg} / \mathrm{kgBB}$ mempunyai efek sebagai antidiare dengan nilai rasio transit intestinal mendekati nilai rasio kelompok normal

\section{DAFTAR RUJUKAN}

[1] Depkes RI. 1999. Buku Ajar Diare. Ditjen P2M \& PLP; Jakarta, 1999

[2] Tjay, T.H. dan K. Rahardja. 2002. Obat-Obat Penting Khasiat, Penggunaan, dan Efek-Efek Sampingnya. Edisi Kelima Cetakan Pertama. Penerbit PT Elex Media : Jakarta.

[3] Abdoerrachman, MH., 2002. Buku Ajar Ilmu Kesehatan Anak: Infeksi dan Penyakit Tropis. Ed ke1.FKUI. Jakarta.

[4] Hakimah. 2010. 81 Macam Buah Berkhasiat Istimewa. Jawa Tengah: Syura Media Utama.

[5] Eilif A. 2007. A Practitioners Perspective Traditional Tannin Treatment Againts Intestinal Parasites in Sheep and Cattle. www.ethno botany journal.org/vol1/155473465-01-031.pdf

[6] Nurhayati. 2015. Aktivitas Antibakteri Ekstrak Etanol Kulit Batang Sawo Manila (Manilkara Achras) Terhadap Staphylococcus Epidermidis Dan Klebsiella Pneumonia Serta Bioautografinya. Universitas Muhammdiyah Surakarta.

[7] Prihardini. 2015. The Development and Antibacteria Test Off Manila Safodilla Leaf (Manikara zapota L.) As a Lotio to Staphyllococcus aures. Jurnal wiyata Vol 2 No.1. Bhakti Wiyata. Kediri.

[8] Enda W.G. 2010. Uji efek antidiare ekstrak etanol kulit batang salam (Syzygium polyanthum (Wight) Walp.) Terhadap mencit jantan. Fakultas farmasi Universitas Sumatra Utara Medan. 